\title{
レオロジー一般 RHEOLOGY IN GENERAL
}

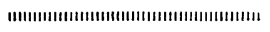

要 旨 ABSTRACT

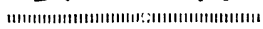

\section{電磁変換式粘弾性測定器の試作*}

\author{
深田栄一** 織田厚** 大平通泰*** \\ 小川成夫*** 奥秋 俊 学*** 小幡 裕 子***
}

\section{Twin Transducers for Measuring the Complex Shear Modulus of Polymers at Audio-Frequencies}

by

Eiichi FukADA, Atsushi OdA

(Kobayashi Institute of Physical Research, Kokubunji, Tokyo)

\section{Michiyasu Ohira, Shigeo Ogawa, Shungaku Okuaki and Hiroko Obata}

(The Textile Research Institute of Japanese Government, Yokohama)

Electromagnetic Transducers, known as Fitzgerald's apparatus, have been widely used in the measurement of dynamic mechanical properties of high polymers. The resonance dispersion in crystalline polymers can only be found by using this apparatus. We have constructed the twin type electromagnetic transducers, following the same principle.

An alminium tube with two coils at both ends is suspended in a magnetic field by eight wires. A pair of disk-shaped specimens is inserted between the tube and a floating mass. When the alternating current is passed through one coil, the specimens are sheared. The electrical impedance of the other coil is measured by a high precision bridge. The mechanical impedance of specimen can be calculated from the difference of electrical impedance measured with specimens and without specimens. The complex shear modulus or compliance is obtained from the mechanical impedance.

The plot of the electrical transfer impedance of tube is smooth over a frequency range from 50 to $8000 \mathrm{cps}$, though a small peak occurs at about $9000 \mathrm{cps}$. The value of transducer constant $K^{2}$, which relates the electrical impedance to the mechanical impedance, has been determined to be $1 \cdot 1 \times 10^{5}$ ohms dynes $\mathrm{sec} / \mathrm{cm}$.

In order to obtain the two effective figures in the value of the complex shear modulus, the measurement with electrical bridge in the precision of five effective figures is necessary. The temperature of apparatus should be kept constant to the accuracy of $0 \cdot 1^{\circ} \mathrm{C}$. The complexity of calculation needs the use of electric calculating machine.

The preliminary experiments on plasticized polyvinyl chloride and irradiated polyethylene have been carried out over a frequency range of 100 to $6000 \mathrm{cps}$.

(Received Feb. 2, 1961)

* 原稿受付 昭和 36 年 2 月 2 日 $* *$ 財団法人小林理学研究所 $* * * *$ 繊維工業試験所 